\title{
Lowering Transport Costs and Prices by Competition: Regulatory and Institutional Reforms in Low Income Countries
}

\author{
Phill Wheat *, Alexander D. Stead $\mathbb{D}$, Yue Huang and Andrew Smith \\ Institute for Transport Studies, University of Leeds, Leeds LS2 9JT, UK; a.d.stead@leeds.ac.uk (A.D.S.); \\ y.huang1@leeds.ac.uk (Y.H.); a.s.j.smith@its.leeds.ac.uk (A.S.) \\ * Correspondence: p.e.wheat@its.leeds.ac.uk
}

Received: 26 July 2019; Accepted: 7 October 2019; Published: 25 October 2019

\begin{abstract}
High passenger and freight transport costs are a barrier to economic growth and social mobility, particularly in Low Income Countries (LICs). This paper considers the current state of knowledge regarding the barriers to achieving lower generalised transport costs. It considers both the road and railway modes across passenger and freight transport. These issues include a reform on the regulations for driver hours (preventing the road infrastructure from overloading), structuring rail concessions, increasing competition, and tackling corruption. Such reforms aim to deliver efficiency gains and service quality improvements at lower costs for users. This paper identifies the knowledge gap in previous research and concludes by setting out a research agenda that builds the evidence base for how the best practices from around the world can best be applied to the specific circumstances in Low Income Countries, with a particular focus on Sub-Saharan Africa and South Asia.
\end{abstract}

Keywords: transport costs; passenger and freight; road and railway; Low Income Countries

\section{Introduction}

Transport is an important enabler of economic growth and society's development [1-3]. Strategic transport along road and rail corridors presents several challenges from a cost, subsidy, and pricing perspective. This is particularly important in low-income countries (LICs), where limited studies have yet to explore economic and mobility needs. Efficient transport services require appropriate funding to meet user needs. These services must be offered at prices that are affordable to facilitate the free flow of goods and services and to increase the mobility of people. Furthermore, a strong oversight of road traffic transit regulations and rail concessions by public authorities is vital for regulatory compliance, including road safety.

This paper addresses a broad set of mode-specific issues, such as road versus rail, and issues common to both road and rail in LICs, specifically aimed at LICs in Sub-Sharan Africa and South Asia. The aim of the paper is to identify both outstanding issues not fully addressed by existing research and such issues that future research, in turn, can help address. Thus, our paper focuses on identifying opportunities for new research. This paper covers issues related to lowering transport costs in terms of the generalised cost of transport. This includes not only financial costs but also the monetary equivalent values of intangible aspects of transport services. Examples include the travel time for shipments and passenger journeys, the associated reliability of that transit time, and service quality aspects, such as the perceived comfort of passenger travel and wider safety considerations impacting users and the broader society (such as other road users in the case of road safety issues).

The role of road transport and rail transport differs both between LICs and high-income countries (HICs) and across different LICs. In HICs, both modes cover freight and passenger movements. Overall, 
road transport is dominant, but rail still has a non-trivial mode share in both the passenger and freight market. In LICs, experience varies. In Sub-Sharan Africa, the lack of railway infrastructure means that, for passenger flows outside of the long distance segment (which is small in any case), the road mode is dominant. As such, the rail transport that exists is biased towards freight. In South Asia, however, LICs can have substantive railway transport focused on passenger flows (for example in Bangladesh and Myanmar).

More broadly, road and rail services are different because roads are open to private users whilst rails have much stronger access restrictions. Studies on the regulation, concession design, and institutional skills requirements for planning, designing, and monitoring transport services have been reviewed. Given the access restrictions in rail, these issues are more applicable to the rail sector. The situation for roads is different, where the state usually provides the infrastructure either directly or indirectly via letting tenders, but private users are also free to use the infrastructure. The issues with respect roads are more focused on regulations on driver hours, road safety, and preventing the over loading of vehicles and tackling corruption. Such reforms aim to deliver efficiency gains and service quality improvements at lower costs for users.

Common to both road and rail are the long and costly clearance times at border crossings. Arvis [4] shows that the cost in the bottom three quintile LICs is three times higher, and its paperwork twice as high as that for the top two quintiles LICs. The literature also indicates that transit time and the reliability of transit impact freight choices and that cross-border delays significantly increase freight tariffs. Existing evidence on alternative technologies that can help improve cross border crossing is also considered. In many LICs, it is clear that the opportunities presented by strategic roads and rails are not being fully realised for a variety of reasons.

Specific experiences in LICs are considered (both in Sub-Sharan Africa and South Asian but also outside of this area), with conclusions identifying opportunities to enhance transport service delivery, costs, and pricing. Our literature search also reflected the experiences and lessons learned from HICs and MICs that can be applied to LICs, especially where the evidence from LICs is sparse on solutions to specific issues (an example being the regulation of driver hours in Section 3.1). The paper concludes by setting out a research agenda that builds the evidence base for how best practices from around the world can best be applied to specific circumstances in LICs. This research agenda will contribute to realising economic growth and social benefits by improving transport services and transit flows.

The structure of this paper is as follows. Section 2 provides an overview of our approach to reviewing the literature. Section 3 reviews road specific issues. Section 4 reviews rail specific issues. Section 5 reviews common issues across the road and rail sectors. Finally, Section 6 synthesises the state of knowledge review into a set of research issues.

\section{Review Methodology}

This paper is a synthesis of the literature. As part of this research project, we undertook a time limited review of literature pertaining to key issues in transport services in LICs and the best practices in responding to these issues across high income countries (HICs), medium income countries (MICs), and LICs. We supplemented our review of databases (described below) with literature on transport services by the project team. Social issues, such as the gender barriers associated with access to transport, were not reviewed as part of this project.

The literature on some of these topics is limited, so the criteria for inclusion were widened in several different ways, so that the review would encompass less specific, but still relevant, studies. Rather than look for literature pertaining specifically to individual countries, or to low-income countries, we searched for any literature on a given topic that was likely to be relevant. For example, several headings relate to rail franchising and regulation. In order to capture a wide range of studies, we entered a few relatively general search terms, such as "railway franchising", and selected publications that seemed relevant to one or more of the headings. These were studies involving low-income countries or studies of high-income countries that were felt to be particularly relevant. 
During the search, we noticed that there is something of a trade-off (though not in all cases) between the relevance of publications and their quality. For example, there are a large number of relatively high-quality publications on the topic of franchising in high-income countries, but not all of these studies are of direct interest here. On the other hand, there tend to be a much smaller number of publications related to low-income countries, and some of these tend to be of lower quality or are not peer-reviewed (e.g., World Bank reports and articles in trade journals). A degree of judgement was made to determine which articles should be included in the review. Indeed, this selection is one of the conclusions of this review, namely the need for high quality, peer reviewed studies on LICs for many of these issues. A second issue was that much evidence from LIC countries was centred around specific case studies. The generalisability of the findings across LICs was unclear, and this result is, again, a conclusion of this review.

We used four databases to search the literature: The Transport Research Information Database (TRID), Web of Science, EconLit, and Google Scholar. TRID integrates the database owned by TRB's Transportation Research Information Services (TRIS) and the OECD's International Transport Research Documentation (ITRD) database. Web of Science is a general, multidisciplinary, citation indexing service, and should yield a comprehensive list of results for a given search term. EconLit is an economics-specific database which we expect will yield sets of results that are more limited, but also more specific and with less irrelevant material. Google Scholar is a freely accessible search engine that covers scholarly literature, including peer-reviewed papers, books, and technical reports across an array of disciplines.

In Table 1 below, we give examples of our approach to the literature search for two of the areas covered in this review: the value of time and the value of reliability for freight transport, and railway concessioning, franchising, and regulation, for two of the databases used (Web of Science and Google Scholar). In addition to deciding on the search terms used, it was necessary to decide which of the results to include in the review. In the case of Web of Science, which returned fewer but more relevant results, we used all relevant results, while for Google Scholar, which typically turns up a much greater number of results, including some which are less relevant, we decided on appropriate cut-off points based on the numbers of relevant results as we moved down the list of results.

Table 1. Example search terms.

\begin{tabular}{|c|c|c|}
\hline Topic & Web of Science Search & Google Scholar Search \\
\hline \multirow{3}{*}{$\begin{array}{l}\text { Value of Time and Reliability for } \\
\text { Freight }\end{array}$} & $\begin{array}{l}\text { TS }=(\text { "value of time" freight } \\
\text { transport) } \\
\text { All relevant results }\end{array}$ & $\begin{array}{l}\text { "value of time" freight transport } \\
\text { Relevant material from first } 15 \text { pages of search } \\
\text { results, ordered by relevance }\end{array}$ \\
\hline & $\begin{array}{l}\text { TS = ("value of travel time } \\
\text { savings" freight transport) } \\
\text { All relevant results }\end{array}$ & $\begin{array}{l}\text { "value of travel time savings" freight transport } \\
\text { Relevant material from first } 15 \text { pages of search } \\
\text { results, ordered by relevance }\end{array}$ \\
\hline & $\begin{array}{l}\text { TS = ("value of reliability" freight } \\
\text { transport) } \\
\text { All relevant results }\end{array}$ & $\begin{array}{l}\text { "value of reliability" freight transport } \\
\text { Relevant material from first } 15 \text { pages of search } \\
\text { results, ordered by relevance }\end{array}$ \\
\hline \multirow{4}{*}{$\begin{array}{l}\text { Railway Franchising, } \\
\text { Concessioning, and Regulation }\end{array}$} & $\begin{array}{l}\text { TS }=\text { (railway concessions }) \\
\text { All relevant results }\end{array}$ & $\begin{array}{l}\text { railway concessions } \\
\text { Relevant material from first } 10 \text { pages of search } \\
\text { results, ordered by relevance }\end{array}$ \\
\hline & $\begin{array}{l}\text { TS = (railway franchising) } \\
\text { All relevant results }\end{array}$ & $\begin{array}{l}\text { railway franchising } \\
\text { Relevant material from first } 10 \text { pages of search } \\
\text { results, ordered by relevance }\end{array}$ \\
\hline & $\begin{array}{l}\text { TS = (railway concession failure }) \\
\text { All relevant results }\end{array}$ & $\begin{array}{l}\text { railway concession failure } \\
\text { Relevant material from first } 10 \text { pages of search } \\
\text { results, ordered by relevance }\end{array}$ \\
\hline & $\begin{array}{l}\text { TS }=\text { (railway infrastructure price } \\
\text { regulation) } \\
\text { All relevant results }\end{array}$ & $\begin{array}{l}\text { railway infrastructure price regulation } \\
\text { Relevant material from first } 10 \text { pages of search } \\
\text { results, ordered by relevance }\end{array}$ \\
\hline
\end{tabular}

In addition, the following sources were found to contain useful reports:

- World Bank and United Nations sponsored project reports. 
- Articles in speciality magazines and media, such as engineering news and toll infrastructure Services.

- Reports by transport consultancies, which are made publicly available.

- Web articles, such as news articles. These are not peer reviewed but may contain insider views, case studies, and recent data.

The following are typical reasons for literature being excluded from the review:

- Only general information pertinent to the subject, e.g., overloading, was found.

- Reference to the data was not provided.

- The full text was not available (only the abstract).

- Information was only found second-hand; we were unable to retrieve the original file.

- A substantive amount of the research that we initially found was done in a European context and there were few implications for elsewhere.

The culmination of our review was to identify a set of issues, which are grouped in Table 2. We will, in turn, discuss in the remainder of this paper the issues that are specific to road transport, rail transport, and issues that are common across the two modes. Within this, approximately 100 papers were found to provide relevant unique contributions to this review.

Table 2. Summary of the issues in road and rail freight transport with references.

\begin{tabular}{|c|c|c|c|c|c|c|c|c|}
\hline & Issues & References & Issues & References & Issues & References & Issues & References \\
\hline $\begin{array}{l}\text { Road Specific } \\
\text { Issues (Section 3) }\end{array}$ & $\begin{array}{l}\text { 3.1 Driver } \\
\text { hours }\end{array}$ & [5-10] & $\begin{array}{l}3.2 \text { Safety } \\
\text { regulation }\end{array}$ & [11-17] & 3.3 Corruption & {$[11,12,18-20]$} & 3.4 Overloading & [21-30] \\
\hline $\begin{array}{l}\text { Rail Specific } \\
\text { Issues (Section 4) }\end{array}$ & $\begin{array}{l}\text { 4.1. Railway } \\
\text { concessioning }\end{array}$ & [31-61] & $\begin{array}{l}\text { 4.2. Economic } \\
\text { regulation }\end{array}$ & {$[37,39,62-67]$} & & & & \\
\hline $\begin{array}{l}\text { Road and Rail } \\
\text { Common Issues } \\
\text { (Section 5) }\end{array}$ & $\begin{array}{l}\text { 5.1. Public } \\
\text { authority and } \\
\text { skills capacity }\end{array}$ & {$[58,68-74]$} & $\begin{array}{l}\text { 5.2. Cross border } \\
\text { road and rail } \\
\text { freight-The } \\
\text { impact of delays }\end{array}$ & {$[4,75-96]$} & $\begin{array}{l}\text { 5.3 Cross border } \\
\text { road and rail freight } \\
\text { solutions - e-border } \\
\text { technology and } \\
\text { standardised } \\
\text { documentation }\end{array}$ & [97-103] & & \\
\hline
\end{tabular}

While we consider our review to be extensive, it is not a systematic review. Instead, it was a time limited review with the scope and approach discussed above. As such we may have missed some relevant literature. However, we note that our review has been subject to review by academic experts selected by the Department for International Development in the United Kingdom. They have helped supplement the material in this review to be evaluated by the academic author team, thereby providing a secondary check, alongside our primary review methodology, to ensure we have not missed key literature.

\section{Road Specific Transport Services Issues}

In the road sector, the primary issues relate to regulation, governance, and the enforcement of regulations. This includes driver hour regulations, road safety regulations, efforts to combat corruption, and vehicle overloading.

\subsection{Regulation of Driver Hours}

The link between working hours and rest time for drivers and the risk of collisions is well established. This suggests the need for regulating drivers' hours of service. Enforcing these hours of service and similar regulations rely upon authorities' ability to inspect company and vehicle records. Technology has progressed from log books, to analogue tachographs, to digital tachographs, which have become progressively more difficult to tamper with and easier to process. Increasingly, as in the UK, it is a requirement that new vehicles be fitted with digital tachographs. The use of digital tachographs suggests the possibility that the authorities may eventually be able to collect data and, therefore, detect infractions in real time. 
McDonald [5] argued that regulating drivers' hours reduced the risk of collisions and highlighted the need for the enforcement of, and adherence to, these regulations. Baas [6] surveyed truck drivers in New Zealand and found high levels of fatigue and sleepiness and also that many drivers exceeded the allowed driving hours. In a review of the literature, Amundsen [7] emphasised the high proportion of professional drivers reporting incidents of fatigue and falling asleep while driving, as well as the link between the length and quality of sleep and accident risk. The authors attributed the low levels of compliance to the complexity of regulations and suggested that harmonisation across countries may improve compliance and safety. Based on a survey of UK truck drivers, Poulter [8] found that perceived behavioural control had the largest effect on compliance with regulations than other 'soft' factors.

Hall [9], using data from the Fatality Analysis Reporting System of the US National Highways Traffic Safety Administration, estimated that a 3-5\% reduction in crashes could be achieved with perfect enforcement of hours of service regulations. Jones [10] compared the working hour regulations in several countries and suggested a 'hybrid' approach to regulation, combining prescriptive measures (e.g., hours of service) and a less prescriptive 'outcomes based' approach. However, overall, there is a lack of evidence related to LICs in this area, which could be studied in future research. The experiences and lessons learned from previous practices in developed economies can be applied to an LIC based on its prevailing conditions.

\subsection{Road Safety Regulation}

Road safety is a particular problem in developing countries, and there has been much discussion of the issue with regard to Africa specifically, where accident and fatality rates have increased along with vehicle ownership [11,12].

Driver licensing and vehicle licensing are generally the responsibility of government agencies. The enforcement of traffic laws and regulations is generally the responsibility of traffic police and courts, while some government agencies have a role in the roadside inspection of freight vehicles.

Assum [13] appraised the road safety initiatives in five African countries: Benin, Côte d'Ivoire, Kenya, Tanzania, and Zimbabwe. The author concluded that each country has the legal framework, organisation, technology, and institutions required for road safety and is aware of effective road safety measures, as well as the scope of the problem. However, a number of weaknesses were identified, such as their lack of political concern and funding, their lower value placed on human life, the weak political positions of their road safety boards, their overreliance on education and information approaches, and their corruption.

Khayesi [14] discussed the growth in road traffic injuries in Africa and the need for governments to improve data collection and analysis, share between agencies, and tackle the problem of under-reporting. Chen [15] noted an ongoing upward trend in road traffic injuries, and identified the lack of leading agencies with regulatory powers and public support as one of the key obstacles to reducing injury rates.

Sumaila [16] discussed the limitations of the Federal Road Safety Corps in Nigeria and recommended restructuring the agency and strengthening the strategic ties with other government departments and agencies to increase their effectiveness. The need for driver education in road safety was also emphasised.

Abegaz [17] analysed the effectiveness of new road safety regulations in Ethiopia. These regulations include bans on the use of mobile phones while driving, driving without a seatbelt, and riding a motorcycle without a helmet, as well as strengthening existing laws on drunk driving, speeding, and unsafe loading. Using data from the period of 2002-2011, the authors found considerable reductions in fatalities and accident rates following the first year after the introduction of these new regulations.

\subsection{Corruption and the Effectiveness of Road Safety Regulation}

Nantulya [11] discussed road traffic injury rates and the reasons for the differing rates and trends across countries, citing corruption as one of the main factors behind high injury rates in developing countries. Kopits [12] found a non-monotonic relationship between GDP per capita and traffic fatality 
rates, that traffic fatality rates increase initially with income, but begin to fall after a threshold income level. The authors noted that, since vehicle ownership rates increase monotonically with income, this turning point reflects reductions in fatalities per vehicle. This inverted-U shaped relationship was also found by Anbarci [18]. Importantly, Anbarci [18] also found that public sector corruption is associated with increased traffic fatalities. Various ways that corruption can affect traffic fatality rates were outlined: corrupt license examiners may allow drivers to bypass training and testing for a fee; corrupt vehicle inspectors may sell safety certificates for unsafe vehicles; and corrupt traffic police may accept bribes to overlook infringements and undermine faith in traffic regulations by extorting money from innocent drivers.

Tackling corruption by public officials is, therefore, important for road safety. Measures could include increased monitoring and detection and the punishment of offenders via some combination of dismissal, fines, and imprisonment. An alternative, or complementary, concept suggested by Becker [19] is to pay efficiency wages above the market-clearing rate, with mark-ups reflecting the potential benefits of corruption and the risk of being caught. This increases the costs of engaging in corruption and may be less costly than increased monitoring. Empirical support for an inverse relationship between wages and corruption was provided by Van Rijckeghem [20].

\subsection{Road Freight Overloading}

Vehicle overloading, where vehicle axle loads exceed pavement design limits, is a specific issue on African roads. This occurs because freight operators overload cargo to maximise their payload and operational efficiency and reduce fuel costs (per tonne-km output). However, overloading significantly affects the life of the highway pavement's asset. Rys [21] studied the effect and concluded that if $20 \%$ of trucks are overloaded, the life of the road pavement reduces by about $50 \%$.

The reason that vehicle overloading is important for examining barriers to lower transport costs is three fold. Firstly, there is a cost impact on the whole system when overloading the road network because the infrastructure deteriorates faster. This ultimately results in a poor use of resources if sufficient resources do exist. At some point, the operators or society will have to pay for this increase in costs. Secondly, in an LIC environment, funds for maintenance and renewal of infrastructures are scarce. Thus, the impact of overloading tends to be that infrastructure quickly degrades into a state that leads to poor quality, resulting in the slowing down and unreliability of road transport. Thirdly, a lack of compliance with overloading regulations can result in the lack of a level playing field between transport providers, which skews competition and enhances corruption in the sector.

To provide insight into the extent of the problem, we highlight three case studies. The World Bank (2005) found that $30 \%$ to $40 \%$ of trucks in India are overloaded by $25 \%$ to $50 \%$. This report contained data on truck operations in India, such as vehicle operating costs, toll rates, and journey times, that can be used in the economic appraisal of overloading and enforcement measures. A case study by Kolo [22] found that $53 \%$ of trucks using a rural road in Nigeria were overloaded. They took a similar approach to Bagui [23] and analysed the percentage and magnitude of overloading separately based on the number of axles and positions (e.g., front and rear) of the axles. Chan [24] showed that the weight limit was exceeded by as much as $100 \%$, and some $50-70 \%$ of heavy trucks were overloaded in a central province of China, compared to $0.5-2 \%$ overloaded in the USA.

Turning to road safety, an overloaded vehicle is difficult to control because it is operated outside the vehicle's design parameters for steering and braking and thus becomes a serious threat to road safety. Overloading leads to increased congestion caused by damaged roads and accidents that increase logistics costs in the region. According to Toll Infrastructure Services [25], transport operators largely welcome overloading control as they value a level playing field that fosters fair competition between modes and operators.

For these reasons, overloading control is a priority, and static weighbridges are used to control overloading. Toll Infrastructure Services [25] have estimated there to be 260 weighbridges in Africa, with plans for another 40 . This quantity of bridges has undoubtedly had a strong beneficial effect. 
Pinard $[26,27]$ has documented the steady reduction in overloading due to weighbridge use in South Africa, Namibia, Zimbabwe, and Zambia. In addition to the technical solution of weighbridges, the decriminalisation of related offences has also produced benefits, according to Pinard [27].

However, static weighbridges have their limitations. They are inflexible and control a load at a specified point but do not cover the whole network. An alternative that has been available for implementation for several years is portable weigh-in-motion (WIM) devices. These devices allow a road authority to set up temporary checks. Though less accurate than static installations, these portable devices are recommended by, for example, Bagui [23]. According to Cottineau [28], overload control using WIM was tried in Taiwan, with a 30\% tolerance margin due to potential measurement errors. This tolerance margin is higher than is desirable. Current research in France [28,29] is aiming to achieve a $10 \%$ tolerance. This, then, is an area where progress can be made, potentially leading to better overloading control.

Alternative technologies are available to monitor and enforce overloading. For example, a framework and field studies have recently been developed for truck overloading and novel control and monitoring methods in China and South Africa. The measures proposed by $\mathrm{Hu}$ [30] include weight sensors installed in vehicles, wireless device sending data to a GPS installed in the driver's cab, and a remote control terminal to receive and process the information sent by the GPS.

Overall, vehicle overloading can be combated by monitoring technology, and there has been instances of success, such as in South Africa, Namibia, Zimbabwe, and Zambia. As we will discuss in Section 5.1, there is also the need for the public authority to have sufficient skills and processes to support technology.

\section{Railway Transport Service Specific Issues}

Unlike access to roads, access to railways must be heavily regulated to ensure the safe and equitable scheduling of services. Railways feature a high fixed cost and low marginal cost and are suited to high volume passenger and freight flows. These high flows present a set of challenges to ensuring viable services. These include concessioning passenger services to achieve better financial value, reducing state subsidy requirements, and stimulating passenger demand. This also raises issues surrounding the extent to which it is optimal to separate transport services from the management of the infrastructure (track and signals) and the regulatory needs around such a separation.

\subsection{Railway Concessioning}

Rail concessioning (also known as rail franchising) has been adopted in Great Britain (GB), Germany, Sweden, and (to a lesser extent) in the Netherlands and Norway. The EU's fourth Railway Package requires competitive tendering of public service railway contracts. A major study was published by the Centre on Regulation in Europe (CERRE) in 2016, drawing on the lessons from GB, Germany, Sweden, and offering suggestions for countries, such as France, who are about to start the tendering process. For the summary report, see Nash [31]. Individual country reports for GB, Sweden, Germany, and France are also available (see Smith [32], Nilsson [33], Crozet [34], and Link [35]).

Typically, rail franchising in Europe has produced cost reductions on the order of 20-30\%. However, Britain has instead seen sharp cost increases (see Smith [32]). In Great Britain, an incoming operator takes over an existing company, rather than bringing his or her own rolling stock and staff. Combined with short franchises that are also net cost contracts, this incentivises a focus on revenue growth rather than cost reduction (see Smith [32]). In addition, British rail franchises may be too large, such that they face diseconomies of scale (see Wheat [36]). Costs and subsidies have risen substantially in France, where there has been no tendering Nash [31]. Affuso [38] used UK data to investigate the relationship between contract length and investment and found that short franchise lengths reduce incentives to invest in some assets. 
Generally, demand has risen strongly in countries that have implemented tendering. However, part of this growth may be related to the "regionalisation" of responsibility for tendering, because France has also seen growth. Nash [31] lists key considerations to be made in future tendering:

- Who should be responsible for franchising (a regional or national body)?

- The size and length of franchises. Evidence suggests that longer franchises may reduce costs [35] and also that large franchises may increase unit costs [35,36].

- Risk Sharing: Evidence from Germany and Sweden suggests that gross cost contracts perform best, although some incentive mechanisms are needed to ensure service quality.

A recurring problem in Great Britain has been franchise failure. This has been less of a problem in other European countries, partly because of their greater use of gross-cost contracts, and possibly because their franchises are much smaller (see Nash [31]). Smith [39] discussed policy responses to franchise failures and their impacts on the performance of Train Operating Companies (TOCs) in GB. These have included placing TOCs on management contracts (these are essentially cost-plus regimes with extra subsidies and, hence, weak incentive properties), short term franchise renegotiations, and placing TOCs temporarily under public ownership. The authors found that the efficiency of TOCs on management contracts deteriorated markedly, but this was not the case with franchise renegotiation. Outside Europe, franchise failure has also been a problem (for example, in Melbourne during the early years of their reforms and in Latin America [40]).

Cruz [41] analysed renegotiations of road and rail concessions in Portugal, where renegotiations have been common, particularly in the very early years of the contract. The authors noted that renegotiation itself is a very costly process, and should be avoided where possible. The authors indicated that the main reasons for contract renegotiation were the inadequate monitoring and enforcement of contract terms and over-optimistic bids.

Outside of Europe, Carbajo [42] pointed to lower public subsidies and increased passenger numbers following rail concessioning in Argentina. They also defined early problems, such as difficulties in enforcing investment plans and imposing fines. Crampes [43] discussed issues in concession contract design, with reference to the Argentine experience, and recommended a form of menu regulation. Under menu regulation, companies choose from a menu of contracts offering different trade-offs between the rate of return, risk, and profit sharing. In choosing their optimal bundle, a company is forced to reveal information about itself to the regulator, which helps to mitigate information asymmetry (the fact that the company knows more about its activities than the regulator). This could potentially lessen the likelihood of regular and costly renegotiations or failures.

Campos [44] found that performance indicators generally improved rail privatisation in Mexico and that concessions may have contributed to reversing railway declines in developing countries. The author concluded that concessions can be a viable approach in developing countries, although care should be taken in concession design.

The analysis of around 1000 concessions in different industries (including the road, rail, energy, water, and telecommunications industries) in Latin America and the Caribbean concluded that concessions can work well [45]. However, the author found that the implementation of the contracts was flawed in many cases, and opportunistic renegotiations should have been dissuaded. Further, he found that most implementation mistakes could have been avoided by improved design and a greater intention to develop incentives.

Guasch [46] emphasised the importance of regulators in reducing the probability of renegotiations. Likewise, Guasch [47] found that regulators and arbitration processes both reduced the probability of government-led renegotiation, while price capping, longer contracts, elections, and growth shocks all increased the probability of renegotiation. Using data on road and rail concessions in Latin America, Estache [48] found that multi-criteria auctions (considering social goals, such as employment) increased the risk of renegotiation but that this problem could be mitigated by high-quality regulations and anti-corruption policies. 
Rodríguez [49] concluded that rail (and road) concessions are more likely to fail if large-scale capital investments are involved, if they are in developing countries, if they involve urban transport, or if they demand uncertainty. Stern [50] emphasised the complementarity of contracting and regulation and the role of an independent regulatory agency in building trust between stakeholders, resolving conflicts, and enabling ordered renegotiations.

Tam [51] discussed three successful and three failed transport infrastructure BOT (build-operate-transfer) concessions in Asia. These were road concessions but are included here, as the findings can transfer to the design of rail concessions, and this study features specific comparisons of LICs and HICs. The authors identified reasonable rates of return, sound mechanisms for the adjustment of terms, strong and technically competent franchisees, and equitable and experienced governments and legal systems as the factors needed for success. Frequent changes in government, corruption, and political interference are identified as factors explaining failure. All three of Tam's (1999) success stories are from an HIC, such as the Hong Kong Special Administrative Region of the People's Republic of China, while all three failures are taken from Thailand, an LIC.

In Kazakhstan, rail reforms from 2005 separated train operation and infrastructure maintenance and encouraged competition in the passenger and freight markets via franchising and open access arrangements, respectively. Sharipov [52] finds that usage and safety both improved, while subsidy levels increased.

Gwilliam [53] stated that 14 of the 30 African countries with state-owned railways use concession arrangements, that four had begun the concession progress, and that only one was operating under a management contract. The rest were subject to political influence. Roy [54] noted that infrastructure investments have tended to remain the preserve of governments and aid agencies.

The introduction of railway concessions in Africa has been accompanied by significant investments in assets, including rolling stocks [54,55], and improvements in productivity [53-55] and allocative efficiency [55]. Budin [56] noted an impressive increase in freight traffic and a substantial improvement in quality of service during the first year of the Abidjan-Ouagadougou railway concession. Roy [54] concluded that there was no indication of an increase in freight rates or that travel for the poor has been made more expensive. Pozzo [57], reviewing railway concessions in Sub-Saharan Africa, found that, due to competition from road transport and clauses against excessive pricing in concession contracts, there was no clear evidence for an abuse of market power. Ndonye [58] evaluated the impact of different public-private partnership (PPP) strategies on the performance of concessions, focusing on the Rift Valley Railways concession in Kenya. A survey of managers indicated a perception that the most important strategic considerations for the performance of concessions are having a strong private consortium as a concession-holder, a sound financial strategy, having a sustainable risk allocation strategy, and investment in technology.

Railway concessions in Africa face significant risks, however. Roy [54] noted the disruptions caused by the civil war in the Ivory Coast and the collapse of a bridge in Malawi. Jones [59] cited political unrest in Kenya in 2008 as affecting the Rift Valley Railways concession, along with political pressure from governments. Pozzo [57] notes the generally weak financial performance of Sub-Saharan African railway concessions and the private sector reluctance to invest in transport in the region or to take on any risk.

Related to the design of rail transport services concessions is its ability to integrate into the management of rail infrastructures (the extent of vertical integration). In Europe, EU legislation has required some form of vertical separation. Countries such as Britain and Sweden have followed full legal separation, whereas others, such as Germany, have used a holding company structure. Mizutani [60] and van de Velde [61] reviewed the literature and provided both quantitative and qualitative assessments of different approaches to separation. A key finding is that, in congested networks, capacity constraints may magnify the misalignment of incentives, such that vertical separation increases costs. This suggests that a holding company or even full vertical integration are preferable. Partly as a result of these studies, European legislation permits both approaches. 
Fair infrastructure access is important, especially when the incumbent operator also manages the infrastructure. This necessitates the independent oversight of track, station, and terminal access charges and capacity allocation in order to ensure that new operators can freely access the infrastructure while adequately compensating the infrastructure manager. This is crucial to enabling the emergence of new operators while ensuring the financial stability of the infrastructure manager.

\subsection{Economic Regulation of Infrastructure and Services}

Transport services tend to operate as (i) directly provided state services, (ii) competition in-the-market (open access), or (iii) competition-for-the market (tendered services). These delivery mechanisms need to be investigated as to the level of protection they provide to final (passenger and freight) users from exploitation.

The 'natural monopoly' property of infrastructure management, i.e., the falling average up to a minimum efficient scale, implies that:

- For a given geographical area, a single firm can achieve lower unit costs than multiple firms.

- Average costs exceed marginal costs, so revenues under marginal usage cost pricing costs are not sufficient for full cost recovery.

- Average cost pricing, however, would make socially desirable services unviable.

- The key trade-off is between the financial viability of the infrastructure manager and the pricing of access for train operators.

A key study in the EU funded project, NETIRAIL-INFRA, examined how cross-industry innovation and cost reduction can be stimulated through a range of regulatory, contractual, and structural approaches (see Nash [37]). Benedetto [62] surveyed regulatory reforms across European railways based on a review of the literature on ideal regulatory characteristics. They found that while European rail regulators generally exhibit many of the features of ideal regulation, there is room for a more proactive approach to shaping the role of track access charges and in regulating the efficiency and quality of infrastructure managers.

Britain has had the most extensive powers of any economic regulator in Europe for many years. This regulator has conducted or commissioned many studies using econometric techniques to determine cost efficiency savings $[39,63,64]$. These have highlighted inefficiencies in Network Rail (the railway infrastructure manager) and have been used for setting cost efficiency targets. This form of benchmarking and price cap regulation (which refers to the setting of limits on the prices or revenue that a firm will receive) is considered to be successful for utilities but is arguably less successful for rail $[65,66]$. Smith [67] showed how the increased powers of economic regulators have contributed to efficiency savings and how these powers interact with other reforms.

\section{Road and Rail Transport Service Issues}

In addition to the issues specific to road and rail freight transport described in the previous two sections, there are issues common to both modes, which are described in this section.

\subsection{Public Authority Capacity and Skills}

There are many instances where transport infrastructure in developing countries has been of low quality, and investment is biased towards 'prestige projects' that may not reflect the most efficient approach for investment [68]. Lee [69] noticed a tendency to focus on investment rather than institutional and regulatory setups and to identify poor financial and environmental sustainability but no comprehensive approaches to poverty, safety, and environmental issues.

Sohail [70] undertook case studies for transport regulation in Sri Lanka, Pakistan, and Tanzania, and highlighted the need for appropriate regulatory frameworks and more effective enforcement.

Mexico provides a useful case study for how public agency skills develop over time. The Agency for Rail Transport (ARTF) was recently established in response to complaints by freight shippers 
about tariffs and service levels. The International Transport Forum [71] compared the capabilities and functions of the ARTF to those of its US and Canadian counterparts, discussed issues in Mexican rail regulation, and outlined priorities for the new regulator. This report highlighted the considerable time needed for ARTF to develop an information base and capabilities comparable to more established regulators and report the recommended discussions with Mexican concession holders and the US and Canadian regulators to determine the financial and operating data that ARTF will need.

Until ARTF's capabilities are fully developed, the ITF recommends a low cost, less prescriptive approach to regulation based on negotiation and arbitration and the continuity of existing safety regulations in the short run. The development of safety regulations based on performance criteria, rather than prescribing certain behaviour and design requirements, was identified as a long-run priority. ITF identified the need for a "critical mass of human skills and management resources spread across law, economics, accounting, and engineering" comparable to that of US and Canadian regulators.

In discussing the regulation of railway concessions in Africa, Gwilliam [53] identified inadequate provisions for regulators as an impediment to effective regulation. The author stated that "many railway concessions in Africa lack formal regulatory structures with real power and are thus susceptible to abuse". In addition, the author listed factors impacting concession performance, including conflicts and delays with the governments over compensation, concession fees, time frames, staffing, administratively imposed salary increases, restrictions on access to container facilities, and unfunded public service requirements.

In the road transport sector, overloading of trucks provides an example of the challenges facing public authorities in LICs. Different institutions are responsible for overload control in different countries, and there are differences in institutional capacities and responsibilities for overload control. Strathman [72] highlights that authorities can influence compliance through changes in both enforcement intensity and the severity of penalties and finds that the marginal effects of these elements in deterring overloading are similar.

The role out of enforcement measures also creates challenges for public authority resources. In particular, alternative routes without weighbridges and the shortfalls in weighbridges necessitate adequate policing of the road network. Overload control strategies should focus on regions and not one stretch of road. Further, Chen [73] suggests that mobile weighbridges could be used to identify severely overloaded trucks before being escorted to weighbridges. However, this "first best" solution would create massive demands for a skilled work force.

Therefore, checking truck weight compliance places high demands on resources, and its efficiency is generally low. In 2014, 20\% of the two million vehicles weighed in South Africa exceeded the weight limit. Only $2.6 \%$ of the $20 \%$ were prosecuted, according to Council for Scientific and Industrial Research reported in Engineering News [74]. Officers accepted bribes and operators paid their way through the weighbridges. Corruption is a major hindrance to compliance. Low fines are imposed, and the practice is seen as 'unimportant' by the Department of Justice [74].

Overall, there is no one solution to combat overloading. However, any solution requires both an investment in technology (weighbridges, etc.) and a strong institutional structure with clear and accountable roles of public authorities and the individuals working within them. This translates to other public authority enforcement activities (such as the road safety enforcement discussed in Section 3.2).

\subsection{Cross Border Road and Rail Freight-The Impact of Delays}

The time to clear goods through customs rises sharply if the goods are physically inspected. Physical inspection is far more prevalent in lower-performing countries, as defined by Arvis [4], because of the quality of their logistics services, and the same shipment may be subject to repeated inspections by multiple agencies. Clearance times for the bottom three quintile $(20 \%)$ performing countries are three times as much, and the paperwork twice as much, as those for the top two quintiles [4]. 
The key business and trade implication of such barriers is that export lead times are nearly four times as long for LICs than for HICs. Thus, the benefits of reducing the time and time uncertainty at borders include increased international trade and investment, new commercial opportunities, access to new materials, reduced input costs, and improved competitiveness.

Using data on landlocked Sub-Saharan African countries, Christ [75] conducted an analysis on the relative size of time costs versus money costs. Christ concluded that time costs (barriers to trade due to time taken to clear customs, for example) generally exceed the monetary costs of trucking. The study suggested that this helps explain why such countries have a comparative advantage in primary commodities, such as metals and agricultural products, while hindering the export of time-sensitive goods. Thus, border and transit delays reduce both the overall volume of trade and the impact of the mix of products traded, which may hinder development.

The extent to which benefits can be realised depends largely on the response of freight operators, and thus the extent to which such improvements reduce freight costs. It is, therefore, important to know the value of time (VOT) and value of reliability (VOR) from the perspective of freight operators.

While there is a large quantity of literature on the estimation of road users' VOT/VOR, much less research has been undertaken regarding the VOT/VOR for freight, particularly in the context of low-income countries. An overview of the methods by de Jong [76] distinguished between the factor cost methods that sum the monetary costs of the factors used (e.g., labour and fuel costs) and modelling approaches, including the revealed preference (RP) (based on an analysis of the impact of various characteristics on modal choices) or the stated preference (SP), which uses survey methods.

Summaries of VOT and VOR findings for rail and road, and overviews of the methods used, are provided by Feo-Valero [77], de Jong [76], and Zamparini [78-80]. A recurring narrative from this literature is that the reliability of journey times is very important to freight shippers [81] and is possibly more important than the journey time itself [82-85].

Shinghal [86] analysed a survey of firms sending freight via the Delhi-Bombay (now known as Mumbai) corridor and found that the reliability of transit times was particularly important for exporters. Larranaga [87] found that reliability and cost were the most important attributes in explaining freight mode choice in Rio Grande do Sul, Brazil. Norojono [88] concluded that safety and reliability were more important factors than travel time in explaining the choice between rail and road freight by Indonesian freight shippers. Similar findings are presented by Arunotayanun [89], who used the same data. These findings complement the HIC studies in suggesting that reliability is paramount.

However, Zamparini [90] found, from an SP survey of the logisitics managers of 24 Tanzanian firms, that reliability was one of the least important service attributes and that transit time and the monetary value of damage and losses is more important. The authors pointed out that this may reflect the challenges facing freight transport in Tanzania, where transport infrastructure is of low-quality compared to other Sub-Saharan African countries and LICs, leading to slow freight and high rates of damage and losses.

Ogwude [91] found that VOT and VOR vary significantly between the shippers of consumer goods and shippers of capital goods in Nigeria. Cundill [92] derived RP VOT estimates for road, rail, and pipeline freight traffic in Kenya and found that modal choice was sensitive to the cost and speed of delivery. In Malaysia, Thomas [93] found that journey time savings due to road improvements resulted in relatively small increases in vehicle utilisation because of other constraints.

Border issues with freight transport are of particular concern in landlocked developing countries (LLDCs), for whom the direct maritime transportation of international freight is not an option. This has been a major impediment to development for LLDCs, which face bottlenecks not only at the seaport but also at each transit country [94].

Zhang [95] analysed VOT in the context of rail freight from Tianjin Port in China to Ulan Bator, the capital of Mongolia. Compared to an average passenger journey time of 32 hours, the average rail freight journey time was 13.1 days: 4.3 days waiting at Tianjin Port, 3.8 days travelling from Tianjin to the Mongolian border, 1.2 days waiting at the border, and 3.8 days from the border to Ulan Bator. The 
authors described the route as being of great importance to landlocked Mongolia, as it is the shortest and most commonly used route to Mongolia's nearest seaport. Border issues derive from the need for the transhipment of freight from road to rail and from the standard gauge railways in China to the broad-gauge railways in Mongolia.

Banomyong [96] compared the various routes available to garment exporters from Laos, another landlocked country. The authors found that their preferred route (i.e., on the grounds of the estimated cost and time) via Malaysia was not the same as that of the most frequently used route via Thailand.

\subsection{Cross Border Road and Rail Freight Solutions: E-Border Technology and Standardised Documentation}

Given the discussion in Section 5.2, measures to improve the flow of goods across borders and through corridors are essential to enable low transport prices and stimulate trade. Customs procedures are becoming increasingly similar worldwide. However, customs is not the only agency in border management. Streamlining border procedures to facilitate trade and simplifying documentation for imports and exports have long been high on the trade development agenda, prompting initiatives to bring border agencies together and create a single window for trade. We have collated findings from research done for countries in Asia and Africa with regard to their barriers and recommended measures.

In Asia, a roadmap for the integration of logistics services was endorsed in 2007 by ASEAN (Association of Southeast Asian Nations) members. The promotion of IT both within and among the parties in the logistics chain are considered conductive to the processing of documents and other trade-related matters. The ultimate goal is to establish an ASEAN single window, adopt a $24 \times 7$ customs operation, and offer provisions in the World Trade Organization (WTO) agreement for customs valuation. Inefficient customs procedures and inspections are considered by De Souza [97] to be the biggest barriers to logistics services in ASEAN. Gupta [98] found that unwieldy customs procedures and inspections, a lack of coordination, and arbitrary rulings are barriers to freer cross-border trade within ASEAN. Tongzon [99] found that the implementation of measures to improve the competitiveness of ASEAN logistics industries has been limited and characterised by a significant perception gap between logistics firms and governments.

In Africa, Adaba [100] examined the effect of an e-government initiative to modernise customs procedures and facilitate trade in Ghana. Hinson [101] found that a $1 \%$ increase in internet use by a country's population is associated with a $2.2 \%$ increase in exports through a reduction in the entry and search costs associated with exporting from Africa. Hoffman [102] suggested that cross-border delays could be reduced by more than $80 \%$ through the interchange of information to facilitate the dynamic scheduling of customs processing capacities and operational changes.

Arvis [103] highlighted issues associated with border crossing in landlocked developing countries (LLDCs). These issues apply to both the Asian and African continent. In response to these challenges, several technologies/systems have been developed in LLDCs to facilitate trade via e-border technology [103]. These include:

- Automated Customs documentation. For instance, UN Conference on Trade and Development (UNCTAD) have developed transit add-ons to Automated System for Customs Data (ASYCUDA).

- The regional integration of national customs, such as the NCTS (New Computerised Transit System) in Europe, allowing the seamless exchange of information, thereby managing both documentation and guarantees.

- The carnet (passport for goods) barcode in e-TIR helps to validate the carnet at border crossings, using a central database accessible by each participating country. RFID technology may also facilitate the tracing of cargo on a corridor and speed up the controls at entry and exit checkpoints.

- Several groups of countries (such as those in Africa) have been experimenting with transit data interfaces facilitating the passing of advance information from country to country, yielding immediate benefits in terms of transit facilitation. 
- The GPS tracking of merchandise. Benefits include helping to build confidence between customs and transit operators and leading to the disuse of inefficient control solutions, such as convoys.

Specifically, on rail transit, the new Annex 9 of the UNECE (United Nations Economic Commission for Europe) International Convention on the Harmonization of Frontier Controls of Goods (the UNECE Harmonization Convention), is expected to streamline railway border crossing procedures through:

- Introducing minimum requirements for border (interchange) stations;

- Co-operating at these stations;

- Moving the controls from borders to the departure or destination stations;

- $\quad$ Reducing the time required for controls;

- Eliminating paper documents;

- Using the CIM (Uniform Rules concerning the Contract of International Carriage of Goods by Rail) / SMGS (Agreement on International Freight Traffic by Rail) common consignment note as a customs document.

It can be seen from the above review that the measures recommended by UNECE will apply to, and improve on, current practices in Asia and Africa.

\section{Discussion and Conclusions: Opportunities for Future Research}

This paper has reviewed the broad state of knowledge for road and rail transport services in LICs. The aim of the paper was to identify outstanding issues not fully addressed by existing research that future research can help address. We have focused on the issues most prevalent to LICs in Sub-Sharan Africa and South Asia. This review has covered a wide range of topics, from franchising and concessioning, to various aspects of safety and economic regulation, to waiting times for border transit. This discussion makes it clear that LICs face considerable challenges in these areas and that resolving these issues will be important to their development. Based on this review, we have identified the following three areas for further academic research. This is not an exhaustive list but a prioritisation of what specific issues academic research can address.

Firstly, we note that this literature review has attempted to draw on the best practices that might be applicable to LICs. In doing so, evidence from LICs (both specifically in Sub-Sharan Africa and South Asia, as well as elsewhere in the world), MICs, and HICs has been considered. However, it is clear, overall, that there is a limited set of systematic evidence specifically for LICs. There are case study examples for LICs (with many examples focusing on the failures rather than successes of their applications, e.g., in concessioning). However, a general finding from the reviewed literature is that in the area of Transport Services for LICs, there is limited research that synthesizes experience across a range of countries. This type of systematic analysis is essential to yield best practice and generalizable findings for LICs. Thus, a key recommendation is the need for a greater quantity of, and more systematic, research in the area of Transport Services in LICs.

Secondly, transporting goods in Africa often takes three times longer and is three to five times more expensive than in Europe, Asia, and Latin America. This literature review has indicated that transit time and reliability affect freight transport choices. This is the case for both LICs and HICs, with evidence of border waiting times for cross-border freight having negative economic impacts on LICs.

Cross-border freight is a major concern for LICs and is stifling trade and economic development, particularly in landlocked countries. Research is needed to establish how new technologies and border process alignments can speed up and improve reliability at border crossings. The economic and social benefits arising from improved transit times would be assessed and, where possible, quantified. This research would need to provide a holistic appraisal of the benefits to improving freight transit across national borders.

Technological solutions at borders, such as developing an ICT infrastructure and smart border control measures, such as non-intrusive inspection and fully paperless systems (e-border) systems, 
will need to be considered. A further key research objective is to enhance freight movements between ports and hinterlands, particularly for Small and Medium Enterprises (SMEs) and others requiring effective freight consolidation services, by formulating a coherent and integrated intermodal strategy. This strategy will involve coordination between transport modes and strategies for the development of 'dry ports' (inland freight depots), free industrial zones, inland customs clearance arrangements, and bonded facilities. Consideration around how to harmonise regulations (such as restrictions on container transport by road) is needed, as are requirements for the employment of competent, trained personnel, which will reduce skill shortages and unofficial payments.

Thirdly, the failure of railway concessions will lead to escalating costs, low-quality service provisions, and, in extreme cases, the termination of services, with substantial societal and economic disruptions. An essential requirement for sustainable rail services in LICs is the design of concessions and establishing optimal regulatory and contracting models and solutions, as well as improving the mode share of passenger transport support and many UN Strategic Development Goals. Railways are inherently safer and, therefore, lead to fewer fatalities and accidents (SDG Target 3.6) and cause less environmental damage (SDG Target 3.9). Providing a viable passenger service as an alternative to road transport will increase the reliability and reduce the environmental impacts of the transport system (SDG Target 9.1).

Research should determine when it is appropriate to separate the management of railway services and infrastructure in LICs and to determine the most appropriate separation models. This would include considering the impact of different institutional and organisational structures for railways and, specifically, vertical separation versus vertical integration and intermediate structures. It should also consider which forms of competition (concessions, open access, or franchising) can best improve the efficiency and societal welfare of railways.

Author Contributions: Conceptualisation and methodology, P.W.; writing-original draft preparation, A.D.S. and Y.H.; writing - review and editing, A.S.

Funding: This research was funded by the UK Department for International Development, grant number HVT/005.

Acknowledgments: This research was funded via UK AID through the UK Department for International Development under the High Volume Transport (HVT) Applied Research Programme, managed by IMC Worldwide. The authors are particularly grateful for the advice of, Bruce Thompson the leader of Theme 1, Long Distance Strategic Road and Rail Transport, of the HVT Programme.

Conflicts of Interest: The authors declare no conflict of interest. The funders had no role in the design of the study; in the collection, analyses, or interpretation of data; in the writing of the manuscript, or in the decision to publish the results.

\section{References}

1. Banister, D.; Berechman, Y. Transport investment and the promotion of economic growth. J. Trans. Geogr. 2001, 9, 209-218. [CrossRef]

2. Venables, A.; Laird, J.J.; Overman, H.G. Transport Investment and Economic Performance: Implications for Project Appraisal; Department for Transport: London, UK, 2014.

3. Farhadi, M. Transport infrastructure and long-run economic growth in OECD countries. Trans. Res. Part $A$ Policy Pract. 2015, 74, 73-90. [CrossRef]

4. Arvis, J.-F.; Ojala, L.; Wiederer, C.; Shepherd, B.; Raj, A.; Dairabayeva, K.; Kiiski, T. Connecting to Compete 2018; World Bank: Washington, DC, USA, 2018.

5. McDonald, N. Safety and regulations restricting the hours of driving of goods vehicle drivers. Ergonomics 1981, 24, 475-485. [CrossRef]

6. Baas, P.H.; Charlton, S.G.; Bastin, G.T. Survey of New Zealand truck driver fatigue and fitness for duty. Trans. Res. Part F Traffic Psychol. Behav. 2000, 3, 185-193. [CrossRef]

7. Amundsen, A.H.; Sagberg, F. Hours of Service Regulations and the Risk of Fatigue- and Sleep-Related Road Accidents; Transportøkonomisk Institutt (Institute of Transport Economics) Report 659/2003; Institute of Transport Economics: Oslo, Norway, 2003. 
8. Poulter, D.R.; Poulter, D.R.; Chapman, P.; Bibby, P.A.; Clarke, D.D.; Crundall, D. An application of the theory of planned behaviour to truck driving behaviour and compliance with regulations. Accid. Anal. Prev. 2008, 40, 2058-2064. [CrossRef]

9. Hall, R.W.; Mukherjee, A. Bounds on effectiveness of driver hours-of-service regulations for freight motor carriers. Trans. Res. Part E Logist. Trans. Rev. 2008, 44, 298-312. [CrossRef]

10. Jones, C.B.; Dorrian, J.; Rajaratnam, S.M.W.; Dawson, D. Working hours regulations and fatigue in transportation: A comparative analysis. Saf. Sci. 2005, 43, 225-252. [CrossRef]

11. Nantulya, V.M.; Reich, M.R. The neglected epidemic: Road traffic injuries in developing countries. BMJ 2002, 324, 1139. [CrossRef]

12. Kopits, E.; Cropper, M. Traffic fatalities and economic growth. Accid. Anal. Prev. 2005, 37, 169-178. [CrossRef]

13. Assum, T. Road Safety in Africa: Appraisal of Road Safety Initiatives in Five African Countries; Sub-Saharn Africa Transport Policy Program Working Paper No. 33; The World Bank: Washington, DC, USA, 1998.

14. Khayesi, M.; Peden, M. road safety in Africa. BMJ 2005, 331, 710. [CrossRef]

15. Chen, G. Road traffic safety in African countries-status, trend, contributing factors, countermeasures and challenges. Int. J. Inj. Control Saf. Promot. 2010, 17, 247-255. [CrossRef] [PubMed]

16. Sumaila, A.F. Road crashes trends and safety management in Nigeria. J. Geogr. Reg. Plan. 2013, 6, 43-62.

17. Abegaz, T.; Berhane, Y.; Worku, A.; Assrat, A. Effectiveness of an improved road safety policy in Ethiopia: An interrupted time series study. BMC Public Health 2014, 14, 539. [CrossRef]

18. Anbarci, N.; Escaleras, M.; Register, C. Traffic fatalities and public sector corruption. Kyklos 2006, 59, 327-344. [CrossRef]

19. Becker, G.S.; Stigler, G.J. Law enforcement, malfeasance, and compensation of enforcers. J. Leg. Stud. 1974, 3, 1-18. [CrossRef]

20. Van Rijckeghem, C.; Weder, B. Bureaucratic corruption and the rate of temptation: Do wages in the civil service affect corruption, and by how much? J. Dev. Econ. 2001, 65, 307-331. [CrossRef]

21. Rys, D.; Judycki, J.; Jaskula, P. Analysis of effect of overloaded vehicles on fatigue life of flexible pavements based on weigh in motion (WIM) data. Int. J. Pavement Eng. 2016, 17, 716-726. [CrossRef]

22. Kolo, S.S.; Jimoh, Y.A.; Ndoke, P.N.; James, O.; Amada, A.Y.; Bala, A. Analysis of Axle Loadings on a Rural Road in Nigeria. Publ. Int. J. Eng. Sci. Invent. 2014, 3, 8-14.

23. Bagui, S.; Das, A.; Bapanapalli, C. Controlling Vehicle Overloading in BOT Projects. Procedia Soc. Behav. Sci. 2013, 104, 962-971. [CrossRef]

24. Chan, Y.C.M. Truck Overloading Study in Developing Countries and Strategies to Minimize its Impact. Master's Thesis, Queensland University of Technology, Brisbane, Australia, 2008.

25. Toll Infrastructure Services. Overloading Control Strategies in Africa; Toll Infrastructure Services: Pretoria, South Africa, 2017.

26. Pinard, M.I. Guidelines on Vehicle Overload Control in Eastern and Southern Africa; Sub-Saharan Africa Transport Policy Programme; The World Bank: Washington, DC, USA, 2010.

27. Pinard, M.I. Emerging Good Practice in Overload Control in Eastern and Southern Africa; Discussion Paper 12, Sub-Saharan Africa Transport Policy Program; The World Bank: Washington, DC, USA, 2011.

28. Cottineau, L.M.; Hornych, P.; Jacob, B.; Schmidt, F.; Dronneau, R.; Klein, E. Automated overload enforcement by WIM. In Proceedings of the 25th World Road Congress, Seoul, Korea, 2-6 November 2015.

29. Jacob, B.; Cottineau, L.-M. Weigh-in-motion for Direct Enforcement of Overloaded Commercial Vehicles. Trans. Res. Procedia 2016, 14, 1413-1422. [CrossRef]

30. Hu, T. A framework of truck overload intelligent monitoring system. In Proceedings of the 2011 Fourth International Symposium on Computational Intelligence and Design, Hangzhou, China, 28-30 October 2011.

31. Nash, C.A.; Crozet, Y.; Link, H.; Nilsson, J.; Smith, A. Liberalisation of Passenger Rail Services: Project Report; Centre on Regulation in Europe: Brussels, Belgium, 2016.

32. Smith, A.S.J. Liberalisation of Passenger Rail Services-Case Study-Britain; Centre on Regulation in Europe: Brussels, Belgium, 2016.

33. Nilsson, J.-E. Liberalisation of Passenger Rail Services: Case Study-Sweden; Centre on Regulation in Europe: Brussels, Belgium, 2016.

34. Crozet, Y. Liberalisation of Passenger Rail Services: Case Study_France; Centre on Regulation in Europe: Brussels, Belgium, 2016. 
35. Link, H. Liberalisation of Passenger Rail Services: Case Study-Germany; Centre on Regulation in Europe: Brussels, Belgium, 2016.

36. Wheat, P.; Smith, A.S.J. Do the usual results of railway returns to scale and density hold in the case of heterogeneity in outputs? a hedonic cost function approach. J. Trans. Econ. Policy 2015, 49, 35-57.

37. Nash, C.; Matthews, B.; Smith, A.S.J. The impact of rail industry restructuring on incentives to adopt innovation: A case study of Britain. Proc. Inst. Mech. Eng. Part F J. Rail Rapid Transit 2018. [CrossRef]

38. Affuso, L.; Newbery, D.M.G. Investment, Reprocurement and Franchise Contract Length in the British Railway Industry; C.E.P.R. Discussion Papers; University of Cambridge: Cambridge, UK, 2000.

39. Smith, A.S.J.; Wheat, P. Evaluating alternative policy responses to franchise failure: Evidence from the passenger rail sector in Britain. J. Trans. Econ. Policy (JTEP) 2012, 46, 25-49.

40. Smith, A.S.J.; Wheat, P.E.; Nash, C.A. Exploring the effects of passenger rail franchising in Britain: Evidence from the first two rounds of franchising (1997-2008). Res. Trans. Econ. 2010, 29, 72-79. [CrossRef]

41. Cruz Carlos, O.; Marques Rui, C. Exogenous determinants for renegotiating public infrastructure concessions: Evidence from Portugal. J. Constr. Eng. Manag. 2013, 139, 1082-1090. [CrossRef]

42. Carbajo, J.; Estache, A. Railway concessions: Heading down the right track in Argentina; World Bank Other Operational Studies; The World Bank: Washington, DC, USA, 1996.

43. Crampes, C.; Estache, A. Regulatory trade-offs in the design of concession contracts. Util. Policy 1998, 7, 1-13. [CrossRef]

44. Campos, J. Lessons from railway reforms in Brazil and Mexico. Trans. Policy 2001, 8, 85-95. [CrossRef]

45. Guasch, J.L. Granting and Renegotiating Infrastructure Concessions; The World Bank: Washington, DC, USA, 2004.

46. Guasch, J.L.; Straub, S. Renegotiation of infrastructure concessions: An overview. Ann. Public Coop. Econ. 2006, 77, 479-493. [CrossRef]

47. Guasch, J.L.; Laffont, J.J.; Straub, S. Concessions of infrastructure in Latin America: Government-led renegotiation. J. Appl. Econ. 2007, 22, 1267-1294. [CrossRef]

48. Estache, A.; Guasch, J.L.; Iimi, A.; Trujillo, L. Multidimensionality and renegotiation: Evidence from transport-sector public-private-partnership transactions in Latin America. Rev. Ind. Organ. 2009, 35, 41. [CrossRef]

49. Rodríguez, D. Expanding the urban transportation infrastructure through concession agreements: Lessons from Latin America. Trans Res Rec. J. Trans. Res. Board 1999, 1659, 3-10. [CrossRef]

50. Stern, J. The relationship between regulation and contracts in infrastructure industries: Regulation as ordered renegotiation. Regul. Gov. 2012, 6, 474-498. [CrossRef]

51. Tam, C.M. Build-operate-transfer model for infrastructure developments in Asia: Reasons for successes and failures. Int. J. Proj. Manag. 1999, 17, 377-382. [CrossRef]

52. Sharipov, T. Results so far and prospects of Kazakhstan passenger rail franchising. Res. Trans. Econ. 2010, 29, 19-35. [CrossRef]

53. Gwilliam, K.M. Africa's Transport Infrastructure; The World Bank: Washington, DC, USA, 2011.

54. Roy, M.-A.; Kieran, P. Rail privatisation rolls across the continent. Int. Railw. J. 2006, 46, 38-41.

55. Bullock, R. Results of Railway Privatization in Africa; Transport Papers, No. TP-8; The World Bank: Washington, DC, USA, 2005.

56. Budin, K.-J.; Mitchell, B. The Abidjan-Ouagadougou Railway Concession; Infrastructure Notes, No. RW-14; The World Bank: Washington, DC, USA, 1997.

57. Pozzo di Borgo, P.; Labeau, A.; Eskinazi, R.; Dehornoy, J.; Parte, A.; Ameziane, M. Sub-Saharan Africa: Review of Selected Railway Concessions; Africa Transport Sector, Report No. 36491; The World Bank: Washington, DC, USA, 2006.

58. Ndonye, H.N.; Anyika, E.; Gongera, G. Evaluation of public private partnership strategies on concession performance: Case of rift valley railways concession, Kenya. Eur. J. Bus Manag. 2014, 6, 145-166.

59. Jones, J.; Murphy, J. The risks are rising for Africa's private operators. Int. Railw. J. 2008, 48, 104-108.

60. Mizutani, F.; Smith, A.; Nash, C.; Uranishi, S. Comparing the costs of vertical separation, integration, and intermediate organisational structures in European and East Asian railways. J. Trans. Econ. Policy (JTEP) 2015, 49, 496-515.

61. Van de Velde, D.; Nash, C.; Smith, A.; Mizutani, F.; Uranishi, S.; Lijesen, M.; Zschoche, F. EVESRail—Economic Effects of Vertical Separation in the Railway Sector; inno-V: Amsterdam, The Netherlands, 2012. 
62. Benedetto, V.; Smith, A.S.J.; Nash, C.A. Evaluating the roles and powers of rail regulatory bodies in Europe: A survey-based approach. Trans. Policy 2017, 59, 116-123. [CrossRef]

63. Smith, A.S.J. The application of stochastic frontier panel models in economic regulation: Experience from the European rail sector. Trans. Res. Part E Logist. Trans. Rev. 2012, 48, 503-515. [CrossRef]

64. Office of Rail and Road. PR18 Econometric Top-Down Benchmarking of Network Rail: A Report; Office of Rail and Road: London, UK, 2018.

65. Smith, A.S.J. Use of Benchmarking by British Regulators: Presentation to a Seminar on Yardstick Competition in Transport; The Italian Regulatory Authority: Turin, Italy, 2017.

66. Smith, A.S.J. Benchmarking Methodologies: With Examples from Rail. In Presentation to a Seminar: The art of ART: Measuring Efficiency for Growth, Development, and Better Quality Transport; The Italian Regulatory Authority: Turin, Italy, 2018.

67. Smith, A.S.J.; Benedetto, V.; Nash, C. The impact of economic regulation on the efficiency of european railway systems. J. Trans. Econ. Policy (JTEP) 2018, 52, 113-136.

68. Button, K. Transport regulation and the environment in low income countries. Util. Policy 1992, 2, $248-257$. [CrossRef]

69. Lee, J.; Hine, J.L. Preparing a National Transport Strategy: Suggestions for Government Agencies in Developing Countries; Transport Papers No. TP-19; The World Bank: Washington, DC, USA, 2008.

70. Sohail, M.; Maunder, D.A.C.; Cavill, S. Effective regulation for sustainable public transport in developing countries. Trans. Policy 2006, 13, 177-190. [CrossRef]

71. International Transport Forum. Establishing Mexico's Regulatory Agency for Rail Transport: Peer Review of Regulatory Capacity. Case-Specific Policy Analysis 2016; Organisation for Economic Co-Operation and Development: Paris, France, 2016.

72. Strathman, J.G. Economics of Overloading and the Effect of Weight Enforcement; Center for Urban Studies College of Urban and Public Affairs Portland State University: Portland, OR, USA, 2001.

73. Chen, Q.; Guo, L. Development of truck overloading automatic detection system based on TPMS. In Proceedings of the 2010 International Conference on Measuring Technology and Mechatronics Automation (ICMTMA 2010), Piscataway, NJ, USA, 13-14 March 2010; pp. 19-21.

74. Engineering News. Available online: http://www.engineeringnews.co.za/print-version/road-transport-201507-24 (accessed on 7 August 2015).

75. Christ, N.; Ferrantino, M.J. Land transport for export: The effects of cost, time, and uncertainty in sub-saharan Africa. World Dev. 2011, 39, 1749-1759. [CrossRef]

76. de Jong, G. Value of Freight Travel-Time Savings. Handbook of Transport Modelling; Hensher, D.A., Button, K.J., Eds.; Elsevier: Amsterdam, The Netherlands, 2007; pp. 649-663.

77. Feo-Valero, M.; Garcia-Menendez, L.; Garrido-Hidalgo, R. Valuing freight transport time using transport demand modelling: A bibliographical review. Trans. Rev. 2011, 31, 625-651. [CrossRef]

78. Zamparini, L.; Reggiani, A. Freight transport and the value of travel time savings: A meta-analysis of empirical studies. Trans. Rev. 2007, 27, 621-636. [CrossRef]

79. Zamparini, L.; Reggiani, A. The value of reliability and its relevance in transport networks: A systems perspective. In Integrated Transport: From Policy to Practice; Givoni, M., Banister, D., Eds.; Routledge: Abingdon, UK, 2010; pp. 97-116.

80. Zamparini, L.; Reggiani, A. The value of travel time savings in passenger a freight transport: An overview. In Policy Analysis of Transport Networks; Van Geenhuizen, M., Rietveld, P., Eds.; Routledge: London, UK, 2016; pp. 161-178.

81. Beuthe, M.; Bouffioux, C. Analysing qualitative attributes of freight transport from stated orders of preference experiment. J. Trans. Econ. Policy (JTEP) 2008, 42, 105-128.

82. Kurri, J.; Sirkiä, A.; Mikola, J. Value of time in freight transport in Finland. Trans. Res. Rec J. Trans. Res. Board 2000, 1725, 26-30. [CrossRef]

83. Bergantino, A.S.; Bolis, S. An analysis of maritime ro-ro freight transport service attributes through adaptive stated preference: An application to a sample of freight forwarders. Eur. Trans. 2004, 25-26, 33-51.

84. Fowkes, A.S.; Firmin, P.E.; Tweddle, G.; Whiteing, A.E. How highly does the freight transport industry value journey time reliability-And for what reasons? Int. J. Logistics Res. Appl. 2004, 7, 33-43. [CrossRef]

85. Hillestad, R.; Van Roo, B.D.; Yoho, K.D. Fast-Forward: Key Issues in Modernizing the US Freight-Transportation System for Future Economic Growth; RAND Corporation: Santa Monica, CA, USA, 2009. 
86. Shinghal, N.; Fowkes, T. Freight mode choice and adaptive stated preferences. Trans. Res. Part E Logistics Trans. Rev. 2002, 38, 367-378. [CrossRef]

87. Larranaga, A.M.; Arellana, J.; Senna, L.A. Encouraging intermodality: A stated preference analysis of freight mode choice in Rio Grande do Sul. Trans. Res. Part A Policy Prac. 2017, 102, 202-211. [CrossRef]

88. Norojono, O.; Young, W. A stated preference freight mode choice model. Trans. Plan. Technol. 2003, $26,1$. [CrossRef]

89. Arunotayanun, K.; Polak, J.W. Taste heterogeneity and market segmentation in freight shippers' mode choice behaviour. Trans. Res. Part E Logistics Trans. Rev. 2011, 47, 138-148. [CrossRef]

90. Zamparini, L.; Layaa, J.; Dullaert, W. Monetary values of freight transport quality attributes: A sample of Tanzanian firms. J. Trans. Geogr. 2011, 19, 1222-1234. [CrossRef]

91. Ogwude, I.C. The value of transit time in industrial freight transportation in Nigeria. Int. J. Trans. Econ./Rivista internazionale di economia dei trasporti 1993, 20, 325-337.

92. Cundill, M.A. Road-Rail Competition for Freight Traffic in Kenya; Transport and Road Research Laboratory Research Report, No. RR 41; Transport Research Laboratory: Wokingham, UK, 1986.

93. Thomas, S. The Value of Time Savings in West Malaysia: Commercial Vehicles; Transport and Road Research Laboratory Research Report, No. HS-036 881; Transport Research Laboratory: Berkshire, UK, 1983.

94. Faye, M.L.; McArthur, J.W.; Sachs, J.D.; Snow, T. The challenges facing landlocked developing countries. J. Hum. Dev. 2004, 5, 31-68. [CrossRef]

95. Zhang, J.; Kawasaki, T.; Hanaoka, S. Freight transport value of time estimation for border crossing route: Case study of Tianjin Port-Ulan Bator route. In Proceedings of the 3rd International Conference on Transport and Logisitics, Malé, Republic of Maldives, 15-17 December 2011.

96. Banomyong, R.; Beresford, A.K.C. Multimodal transport: The case of Laotian garment exporters. Int. J. Phys. Distrib. Logistics Manag. 2001, 31, 663-685. [CrossRef]

97. De Souza, R.; Goh, M.; Gupta, S.; Lei, L. An Investigation into the Measures Affecting the Integration of ASEAN's Priority Sectors (Phase 2): The Case of Logistics; ASEAN: Jakarta, Indonesia, 2018.

98. Gupta, S.; Desouza, M.G.R.; Garg, M. Assessing trade friendliness of logistics services in ASEAN. Asia Pac. J. Mark. Logistics 2011, 23, 773-792. [CrossRef]

99. Tongzon, J.; Cheong, I. The challenges of developing a competitive logistics industry in ASEAN countries. Int. J. Logistics Res. Appl. 2014, 17, 323-338. [CrossRef]

100. Adaba, G.B.; Rusu, L. E-trade facilitation in Ghana: A capability approach perspective. Electron. J. Inf. Syst. Dev. Ctries. 2014, 63, 1-13. [CrossRef]

101. Hinson, R.E.; Adjasi, C.K.D. The Internet and export: Some cross-country evidence from selected African countries. J. Int. Commer. 2009, 8, 309-324. [CrossRef]

102. Hoffman, A.; Bhero, E. A simulation approach to the optimized design of cross-border operations. In Proceedings of the 2015 IEEE 18th International Conference on Intelligent Transportation Systems, Las Palmas, Spain, 15-18 September 2015.

103. Arvis, J.-F.; Carruthers, R.C.; Smith, G.; Willoughby, C. Connecting Landlocked Developing Countries to Markets; The World Bank: Washington, DC, USA, 2011.

(C) 2019 by the authors. Licensee MDPI, Basel, Switzerland. This article is an open access article distributed under the terms and conditions of the Creative Commons Attribution (CC BY) license (http://creativecommons.org/licenses/by/4.0/). 